\title{
Strategic Responses of Advanced Economies to the Belt and Road Initiative
}

Jason Young

\begin{abstract}
Responses to the Belt and Road Initiative (BRI) have been mixed. Many commentators have welcomed the opportunity for infrastructure development and projects to build economic, political and social connectivity across the region. Others have been openly critical or slow to formulate a clear position. In general, advanced economies have responded less positively than developing economies. This paper employs a constructivist approach to interpret responses to the BRI in advanced economies through analysis of commentary in the United States, the European Union, Japan, Australia and New Zealand. It identifies a diversity of responses within and among these economies and a strong ideational coherence in the frameworks used to assess the BRI. It is concluded that the reception of Chinese-promoted concepts in international affairs, like the BRI, remains challenging due to the dominance of liberal and realist
\end{abstract}

Jason Young is Director of the New Zealand Contemporary China Research Centre and Associate Professor of International Relations at Victoria University of Wellington. His mailing address is: 18 Kelburn Parade, PO Box 600, Wellington 6140, New Zealand. He can also be reached at jason.young@vuw.ac.nz.

(c) 2018 World Century Publishing Corporation and Shanghai Institutes for International Studies China Quarterly of International Strategic Studies, Vol. 4, No. 3, 381-399

DOI: 10.1142/S2377740018500197

This is an Open Access article, copyright owned by the SIIS and WCPC. The article is distributed under the Creative Commons Attribution 4.0 (CC BY-NC) Licence. Further distribution of this work is permitted, provided the original work is properly cited and for non-commercial purposes. 
assessments and the accompanying political values. This suggests a need for greater intellectual engagement and more substantial feedback between China and the advanced economies, so as to open the way for a long overdue regional conversation on how development is conceptualized and co-created in a region with diverse approaches to regional economic policy.

Keywords: Belt and Road Initiative (BRI); "China solution"; ideological gap; strategic concern.

\section{Introduction}

The Belt and Road Initiative $(B R I)^{1}$ has received mixed responses in advanced economies since it was first announced in 2013. Many commentators see the BRI as an opportunity to promote regional trade, development and economic connectivity through infrastructure and cooperation agreements. Critics, however, raise questions about the strategic implications of the BRI and the impact it could have on norms and standards underpinning the regional economic and security order. Some take a zero-sum approach, worrying that China will gain influence through the BRI at the expense of the United States or other advanced economies. Many commentators express a degree of puzzlement or frustration when trying to define and explain the BRI. As a result, governments in the advanced economies have responded cautiously to the initiative.

This paper focuses on the strategic considerations and responses to the BRI in the world's advanced economies, typically Western multi-party liberal democracies, and questions why they have responded as they have. Most commentary on the BRI has focused on assessing projects and responses from countries with developing economies, because they are the primary participants in the BRI to date. Others focus on better understanding the strategic rationale of China in advancing the initiative. Many studies have assessed their potential involvement, with studies in developing countries tending to have a more positive appraisal overall.

\footnotetext{
${ }^{1}$ This paper uses the now standard BRI formulation but quotes and other commentary may still use "One Belt, One Road (OBOR)." Both refer to yidaiyilu, a combined reference to the 21st-Century Maritime Silk Road and the Silk Road Economic Belt.
} 
Scholars and governments in advanced economies have not responded as enthusiastically, making them an ideal group to study. Without buy-in from advanced economies, the BRI could face challenges in third markets and a deepening and perhaps even geographical enlargement of the current strategic competition/rivalry between China and the United States. Focusing on the responses of the advanced economies can therefore help us understand their strategic thinking around potential involvement, the reach and reception of the BRI as a strategic concept, as well as the areas most challenging and most in need of reform from the perspective of today's advanced economies.

This paper defines an advanced economy on the basis of the economic categories employed by the International Monetary Fund (IMF) World Economic Outlook. ${ }^{2}$ The IMF distinguishes between advanced, emerging markets and developing economies on the basis of per capita income levels, export diversification and degree of integration into the global financial system. On this basis, the paper has selected the major advanced economies of the United States, the European Union (as a proxy for the advanced economies in Europe), Japan, Australia, and New Zealand. These cases provide a good pool of responses from which to draw out the general pattern of advanced economy responses to the BRI.

The paper is focused on the responses of scholars, policymakers, and commentators. These responses are informed by socially constructed understandings of the world, ${ }^{3}$ state identity, ${ }^{4}$ and materialist considerations of zero-sum and positive-sum gain. Because realism and liberalism remain the dominant theoretical positions employed by scholars and policymakers in the advanced economies, the paper pays special attention to these foreign policy frames. ${ }^{5}$ Findings show that realist and liberal

2“Frequently Asked Questions: World Economic Outlook (WEO)," International Monetary Fund, https://www.imf.org/external/pubs/ft/weo/faq.htm\#q4b.

${ }^{3}$ Alexander Wendt, "Anarchy Is What States Make of It: The Social Construction of Power Politics," International Organization, Vol. 46, No. 2 (1992), pp. 391-425.

${ }^{4}$ Ted Hopf, "The Promise of Constructivism in International Relations Theory," International Security, Vol. 23, No. 1 (1998), pp. 171-172.

${ }^{5}$ John Baylis, Steve Smith, and Patricia Owens, eds., The Globalization of World Politics: An Introduction to International Relations (Oxford: Oxford University Press, 2014). 
conceptualizations continue to dominate the commentary around the BRI in these economies.

The paper employs a constructivist approach to identify and interpret the dominant narratives around the BRI in the advanced economies. This provides insight into the dominance of existing analytical frames as a way of categorizing and assessing the BRI and highlights the difficulty that Chinese concepts like the BRI face when received Advanced economies are often cautious about the BRI due to realist and liberal thinking. within this analytical context. Constructivism also provides a means of situating the reception of the BRI within the broader debates about China's place in the world and underscores the importance of ideas in the study of international relations.

China's engagement in world affairs is underpinned, to some extent, by a differing conceptual understanding of International Relations (IR) to that which is dominant in the advanced economies. This derives from the different historical experience China has had with the international system, as well as the differences in political, economic and social values and interests in contemporary times. China was weak and largely isolated when the international system emerged in the post-war years and has arguably struggled to integrate fully into that system due in part to changing expectations from the advanced economies, ${ }^{6}$ and in part to China's promotion of international pluralism. ${ }^{7}$ China has, until recently, been viewed largely as a rule taker rather than a rule maker. ${ }^{8}$ The BRI, as a Chinese-led initiative, signals a shift in China's role in international affairs to one of greater agency, more ambition, and more initiative. This shift is echoed in academic and policy writing within China.

${ }^{6}$ Zhang Yongjin, "China's Entry Into International Society: Beyond the Standard of 'Civilisation,"' Review of International Studies, Vol. 17, No. 1 (1991), pp. 3-16.

${ }^{7}$ Zhang Yongiin, "China and Liberal Hierarchies in Global International Society: Power and Negotiation for Normative Change," International Affairs, Vol. 92, No. 4 (2016), pp. 795-816.

${ }^{8}$ James Reilly, "A Norm-taker or a Norm-maker? Chinese Aid in Southeast Asia," Journal of Contemporary China, Vol. 21, No. 73 (2012), pp. 71-91. 
China is experiencing what Wang Xuedian describes as a "nativist turn" in the humanities and social sciences. ${ }^{9}$ This turn is accompanied by a new-found sense of pride and assertiveness in international affairs, ${ }^{10}$ which sees Chinese academics, policymakers, and commentators not only presenting China's interests in world affairs but also seeking to set the agenda of discussion, to define the conceptual paradigm for regional issues, and to come up with new ideas based on China's own experience and intellectual history. In the area of development, this is sometimes referred to as the "China solution." 11

Wang argues that "China's indigenization movement in politics, economics, and law will place the Chinese experience on a level of theoretical abstraction that will become an impetus for Western academia to reconsider the consensus on what constitutes universal law."12 Such a process is arguably long overdue, but it is also a process fraught with political difficulty as this paper illustrates. The BRI represents the active promotion of Chinaoriginated ideas in a world dominated by scholars and policymakers in the advanced economies. It signals a new search for Chinese agency in world affairs, which is arguably the most challenging aspect of the BRI for commentators in advanced economies who have become accustomed to the ideas that define, describe and shape the world originating in the Westerndominated IR cannon. It is a stark reversal of the socialization debate.

China's role in the world has been conceptualized as a historical process of socialization to global norms and institutions, ${ }^{13}$ reform toward the standards and norms of international society, ${ }^{14}$ and/or the liberal

${ }^{9}$ Wang Xuedian, "Where Is China Headed? New Tendencies in the Humanities and Social Sciences," Journal of Chinese Humanities, Vol. 3, No. 2 (2017), pp. 156-176.

${ }^{10}$ Yan Xuetong, "From Keeping a Low Profile to Striving for Achievement," Chinese Journal of International Politics, Vol. 7, No. 2 (2014), pp. 153-184.

${ }^{11}$ See, for example, Laurence Brahm, “China Solution' Is Diversified Solution," China Daily, January 19, 2018, http://www.chinadaily.com.cn/a/201801/19/WS5a613485a3106e7dcc 1352f4.html.

${ }^{12}$ Wang Xuedian, "Where Is China Headed? New Tendencies in the Humanities and Social Sciences."

${ }^{13}$ See, for example, Alastair Iain Johnston, Social States: China in International Institutions, 1980-2000 (Princeton: Princeton University Press, 2007).

${ }^{14}$ Gerrit W. Gong, The Standard of "Civilisation" in International Society (Oxford: Clarendon Press, 1984), p. 276. 
international order. ${ }^{15}$ Little effort has been put into researching Chinese ideas and norms in IR, arguably due to China's recent emergence as a great power and significant differences in how ideas are generated in IR scholarship. As Pu Xiaoyu argues, however, "socialisation [is] a two-way process"; "emerging powers will change the distribution of material power and also challenge the Western domination of ideas and norms in international society." ${ }^{16}$ The BRI, as a collection of Chinese policymaking and intellectual conceptualizing, provides the opportunity to explore how this process is received by the advanced economies.

Nevertheless, as Qin Yaqing reminds us, we are yet to witness the emergence of a coherent Chinese school of international relations, ${ }^{17}$ and are unlikely to for some time, but there is ample evidence that China employs new concepts in an effort to explain or rationalize its evolving place in the world. ${ }^{18}$ An example of such indigenous theorizing is Yan Xuetong's exploration of historical writings and promotion of the idea of moral realism. ${ }^{19}$ Another is Zhao Tingyang's application of the Confucian Tianxia system to contemporary world governance and order. ${ }^{20}$

In general, however, Chinese IR follows the meta-narratives set by the state in close collaboration with leading think tanks and Community Party of China (CPC) intellectuals. Western scholars are reluctant to accept China's state-promoted IR concepts. Examples of "state-led theorizing" include

${ }^{15} \mathrm{G}$. John Ikenberry, "The Rise of China and the Future of the West: Can the Liberal System Survive?," Foreign Affairs, Vol. 87, No. 1 (2008), pp. 23-37.

${ }^{16} \mathrm{Pu}$ Xiaoyu, "Socialisation as a Two-way Process: Emerging Powers and the Diffusion of International Norms," The Chinese Journal of International Politics, Vol. 5, No. 4 (2012), pp. 341-367.

${ }^{17}$ Qin Yaqing, “Why Is There No Chinese International Relations Theory?," International Relations of the Asia-Pacific, Vol. 7, No. 3 (2007), pp. 313-340.

${ }^{18}$ Qin Yaqing, "Development of International Relations Theory in China: Progress Through Debates," International Relations of the Asia-Pacific, Vol. 11, No. 2 (2011), pp. 231-257.

${ }^{19}$ Yan Xuetong, Ancient Chinese Thought, Modern Chinese Power (Princeton: Princeton University Press, 2011).

${ }^{20}$ Zhao Tingyang, Tianxia Tixi: Shijie Zhidu Zhexue Daolun [Tianxia System: Introduction to the Philosophy of World Institutions] (Nanjing: Jiangshu Higher Education Publishing House, 2005). 
"peaceful development," a "new type of international relations/great power relations," "community of shared future for mankind," and the BRI. A state-led approach to the generation and management of leading IR concepts and a lack of clear distinction between government policy and IR theorizing tends to make IR scholars in advanced economies reluctant to use such concepts. As a result, Chinese concepts in IR have struggled to gain traction in the advanced economies where scholars and policymakers remain resistant to state-promoted ideas.

As this paper demonstrates, the BRI represents a move toward a turning point in China's relations with the world and a shift toward China becoming a net exporter of IR concepts where previously it has been a net importer. It demonstrates the challenge the BRI presents to scholars and policymakers in advanced economies when dealing with ideas that do not fit neatly into the dominant realist and liberal IR canon, and a strong reflex toward conceptualizing the BRI within these paradigms.

\section{Advanced Economy Responses to the BRI}

This section presents a summary of commentators and government responses in the major advanced economies of the United States, the European Union, Japan, Australia, and New Zealand.

\section{The United States}

Research from think tanks in the United States largely focuses on China's strategic goals for the BRI and the impact on partner countries. They are reluctant to take the stated aims of the initiative at face value. Instead, they assert that the BRI is designed to help China address its excess capacity in industries such as steel and cement and to increase China's influence in regional affairs for China's benefit. They argue that increasing regional infrastructure projects could boost external demand for Chinese industry and conceptualize the BRI as a response to the structural challenges that afflict China's growth model, namely, a reliance on state-owned enterprises (SOEs) and state-subsidized finance leading to over-investment. The BRI is viewed as a way for China to double-down on its growth model by finding new markets where it can continue infrastructure development using SOEs and state finance. The BRI is therefore viewed warily by scholars who see a risk of China "exporting the weaknesses in China's 
economic growth model throughout the region" ${ }^{21}$ or who believe China is attempting to increase its economic leverage for political influence through "debt diplomacy." 22

Not all academics, however, are this skeptical, with some viewing the BRI as China becoming a more globally engaged and responsible great power. For example, Joseph Nye argues that the BRI will provide China with geopolitical gains as well as costs and is unlikely to be much of a game changer in its overall grand strategy. He suggests the United States should welcome the BRI, because it is evidence that China is willing to contribute more to the provision of global public goods and become a "responsible stakeholder." Moreover, Nye argues that there could be opportunities for American companies to benefit from BRI investments, and that engagement could go some way to addressing what he describes as China's "self-containment." Nye worries that nationalism remains a most powerful force in China and therefore increasing engagement between the United States and China remains crucial. ${ }^{23}$

The political response to the BRI in the United States has moved considerably over the years. Under the Obama administration, officials noted that China's BRI plans mirrored the intent of the U.S. New Silk Road Initiative (NSR) from 2011, ${ }^{24}$ and argued the BRI could be "mutually reinforcing" of U.S. efforts to support peace, stability, and prosperity through economic opportunity and

The U.S. response to the BRI has deteriorated sharply as U.S.-China strategic competition escalates.

${ }^{21}$ Joshua P. Meltzer, “China's One Belt One Road Initiative: A View from the United States," Brookings Institution, June 19, 2018, https://www.brookings.edu/research/chinasone-belt-one-road-initiative-a-view-from-the-united-states/.

22“Aid Not 'Neocolonialism' or 'Wasteful,"' China Daily, September 6, 2018, http://usa. chinadaily.com.cn/a/201809/06/WS5b906f04a31033b4f4654777.html.

${ }^{23}$ Joseph S. Nye, “Xi Jinping's Marco Polo Strategy," Project Syndicate, June 12, 2017, https://www.project-syndicate.org/commentary/china-belt-and-road-grand-strategy-byjoseph-s-nye-2017-06?referrer=/hIvDtqNTZ7.

${ }^{24}$ Joshua Kucera, “Clinton's Dubious Plan to Save Afghanistan with a 'New Silk Road,"' The Atlantic, November 2, 2011, https://www.theatlantic.com/international/archive/ 2011/11/clintons-dubious-plan-to-save-afghanistan-with-a-new-silk-road/247760/. 
connectivity in one of the least-economically integrated regions of the world. ${ }^{25}$ Similarly, the early Trump Administration announced the conclusion of a U.S.-China trade deal on the import of beef from China, with "recognition of the importance" of China's BRI. However, as the Trump Administration hit bumps in its relationship with China, particularly over the trade deficit and accusations of unfair economic practice and industrial policy, such as the "Made in China 2025" policy, ${ }^{26}$ a more geostrategic and concerned U.S. government view emerged.

Competition has come to the fore. The U.S. National Security Strategy framed China as targeting "investments in the developing world to expand influence and gain competitive advantages against the United States." ${ }^{27}$ Similarly, U.S. Secretary of State Rex Tillerson argued that "China continues its concerted and coordinated effort to compete with the United States in diplomatic, military, and economic terms," ${ }^{28}$ pointing out that while it "is not our intent to contain China's economic growth," the United States does "pay close attention to their OBOR policy." ${ }^{29}$

U.S. opposition to the BRI focuses on two related issues. Firstly, there is concern that the BRI could undermine the international rules-based system. Rex Tillerson has stated that as "part of the global order, the international system of rules and norms.......China can choose to carry out its OBOR

${ }^{25}$ Richard Chang, “One Belt, One Road: Opportunities for U.S.-China Cooperation in 2017," US-China Dialogue, January 16, 2017, https://uschinadialogue.georgetown.edu/ responses/one-belt-one-road-opportunities-for-u-s-china-cooperation-in-2017.

${ }^{26}$ Paul Dupont, “Made in China 2025-China's Industrial Vision and New Zealand," New Zealand Contemporary China Research Centre, July 6, 2018, https://www.victoria.ac. nz/__data/assets/pdf_file/0005/1660811/Made-in-China-2025-Chinas-Industrial-Vision-andNew-Zealand.pdf.

27 “China in U.S. National Security Strategy Reports, 1987-2017," US-China Institute, December 18, 2018, https://china.usc.edu/china-us-national-security-strategy-reports-19872017.

${ }^{28}$ Mike Pompeo, "Excerpts from CIA Director Pompeo's Prepared Remarks," White House, April 11, 2018, https://www.whitehouse.gov/briefings-statements/excerpts-ciadirector-pompeos-prepared-remarks/.

${ }^{29}$ Rex Tillerson, "No Intent to Contain China's Growth," Times of India, December 13, 2017, https://timesofindia.indiatimes.com/world/us/no-intent-to-contain-chinas-growth-us/ articleshow/62053286.cms. 
within that system, or it can try to redefine that." ${ }^{30}$ Secondly, U.S. opposition shows concern for the U.S. strategic position relative to China's. It is widely believed that "China has the capacity to present the greatest rivalry to America of any over the medium and long term." ${ }^{31}$ Likewise, "Their efforts to establish all these different programmes, the belt and road initiative.......they're not just efforts to create new overland trade corridors, they're efforts to basically make these nations economically, politically and eventually militarily dependent on and vulnerable to China., ${ }^{32}$

While concerned and attentive, the United States remains confident of its ability to compete with China and frames the BRI as such. ${ }^{33}$ The U.S. response to the BRI has therefore shifted from strategic engagement to strategic competition and even rivalry, reflecting a broad trend in U.S.China relations under the Trump administration. Concern for international standards and the rules-based system has given way to concern for maintaining U.S. interests and strategic position in world affairs.

\section{The European Union}

Debate within the EU tends to focus more on the principles underpinning BRI engagement. Critics focus on the reluctance to move toward multilateral mechanisms for governing the BRI and the absence of the values of the $\mathrm{EU}$, such as good governance, rule of law, human rights and democracy. ${ }^{34}$ As such, the European Union remains reluctant to unanimously support the BRI. EU leaders argue that any scheme connecting Europe and Asia should

${ }^{30}$ Ibid.

${ }^{31}$ Ankit Panda, "In Mike Pompeo, Donald Trump Has the Enabler for His Multifaceted China Policy," South China Morning Post, March 15, 2018, https://www.scmp.com/news/ china/diplomacy-defence/article/2137245/mike-pompeo-donald-trump-has-enabler-hismultifaceted.

32 “China A Strategic Challenge to USA, Says CIA Director Mike Pompeo," Times Now, April 13, 2018, https://www.timesnownews.com/international/article/china-a-strategic-challenge-to-usa-says-cia-director-mike-pompeo/217091.

33“'No Intent to Curb China's Growth, Can Carry Out One Belt One Road Within System': US," NDTV, December 13, 2017, https://www.ndtv.com/world-news/attending-toobor-but-no-intent-to-contain-chinas-growth-says-us-secretary-of-state-1787058.

${ }^{34}$ Siegfried Wolf, "New Silk Road and China's Hegemonic Ambitions," Deutsche Welle, May 15, 2017, http://www.dw.com/en/new-silk-road-and-chinas-hegemonic-ambitions/a38843212 . 
adhere to the principles that define the EU, namely, market rules, transparency, sustainability and international standards, and should complement existing networks and policies. ${ }^{35}$ EU lawmakers voted against China's application for "market economy status" in the World Trade Organization (WTO) over similar concerns. ${ }^{36}$

\section{The EU worries that the BRI would challenge basic EU norms and values.}

But overall, there is arguably no unified policy toward the BRI in Europe. ${ }^{37}$ Chinese investment has caught the attention of some European politicians. Infrastructure investment, such as investment in Athens' Piraeus Harbor, is indicative of the attention paid by some European states. ${ }^{38}$ Moreover, the prime ministers of Italy, Spain, Hungary and Greece as well as the Polish President all attended the BRI Forum in Beijing in 2017. But there has also been strong European criticism of the BRI with 27 of the 28 national EU ambassadors, that it "runs counter to the EU agenda for liberalizing trade and pushes the balance of power in favor of subsidized Chinese companies." Frustrations stem from concern that EU nations do not receive access to Chinese investment opportunities and that Chinese companies undertake most BRI projects. They have called for increased transparency in the procurement process and careful consideration before entering into any BRI agreements. $^{39}$

35 "Speech by Jyrki Katainen, Vice President of the European Commission at the Leaders' Roundtable of the Belt and Road Forum for International Cooperation," European Commission, May 15, 2017, http://europa.eu/rapid/press-release_SPEECH-17-1332_en.htm.

36 “European Parliament Resolution of 12 May 2016 on China's Market Economy Status," European Parliament, May 12, 2016, http://www.europarl.europa.eu/sides/getDoc.do? pubRef=-//EP//TEXT+TA+P8-TA-2016-0223+0+DOC+XML+V0//EN.

${ }^{37}$ Philipe Le Corre, “Europe's Mixed Views on China's Belt and Road," Lowy Institute, May 23, 2017, https://www.lowyinstitute.org/the-interpreter/europe-s-mixed-views-china-sbelt-and-road.

38 “COSCO Sees Greece's Piraeus Among World's Top 30 Ports by 2018," Reuters, September 23, 2016, http://www.reuters.com/article/us-greece-cosco-piraeus-idUSKCN11 S268.

${ }^{39}$ Dana Heide, Stephan Hoppe, Scheuer Till, and Stratmann Klauss, "EU Ambassadors Band Together Against Silk Road," Handelsblatt Global, April 17, 2018, https://global. handelsblatt.com/politics/eu-ambassadors-beijing-china-silk-road-912258. 
In short, the BRI has been criticized on the basis of international standards and best practice, but there is less of a focus on the zero-sum logic that characterizes U.S. commentary on the BRI. The states of Europe remain open to participating in the BRI if certain conditions are met, namely those conditions promoted in Europe's own international engagement.

\section{Japan}

In Japan, a number of scholars have taken a hard line on the BRI echoing the U.S. position, while others have sought to link up Japan's own infrastructure projects in Asia with the BRI under conditions similar to those stipulated by the EU. At one end of the spectrum, the BRI is viewed as part of an effort to launch a China-centric economic sphere. These scholars argue that Japan feels closely the uncertainty of China's political and military rise and fears a China-centric system overriding the liberal, open, and rules-based order Japan has prospered under. Any assessment of the BRI should therefore carefully consider China's overarching geopolitical ambitions. ${ }^{40}$ At the other end of the spectrum, scholars argue that there are opportunities to link up Japan's own extensive infrastructure investment in the BRI region.

The Japanese government was initially very skeptical of the BRI, especially on the issue of transparency. It presented its own Japan Infrastructure Initiative $(\mathrm{JII})^{41}$ for infrastructure projects such as railways and power plants in Asia and Africa. ${ }^{42}$ However, in a speech in Tokyo in June 2017, Prime Minister Abe softened his position and argued the BRI has the

${ }^{40}$ Toshihiro Nakayama, “Japan's Strategic Choices in A Dangerous World,” Sir Howard Kippenberger Public Lecture, August 24 2017; and Toshiro Nakayama, "NZ and Japan See a Different China," May 16, 2017, http://www.asianz.org.nz/bulletin/new-zealand-and-japansee-a-different-china.

41 “Japanese Companies Team Up to Fund Infrastructure Exports," Nikkei Asian Review, December 1, 2016, https://asia.nikkei.com/Business/Japanese-companies-team-up-to-fundinfrastructure-exports.

${ }^{42}$ Arthur Dominic Villasanta, “Abe Derailing China's Silk Road Economic Project with Japan Infrastructure Initiative," China Topix, December 2, 2016, http://www.chinatopix.com/ articles/107299/20161202/japan-derailing-china-s-silk-road-economic-project-multibilliondollar.htm\#ixzz4nW8NBDC4. 
"potential to connect East and West as well as diverse regions found in between." Abe noted that Tokyo was "ready to extend cooperation" on the condition that it will be in "harmony with a free and fair trans-Pacific economic zone," that the infrastructure built will "be open to use by all" and "developed through procurement that is transparent and fair," and that the projects will "be economically viable and financed by debt that can be repaid and not harm the soundness of the debtor nations' finances." ${ }^{43}$

\section{Australia}

In Australia, security scholars argue that the BRI presents a risk to Australia's strategic interests. ${ }^{44}$ Like Japan, these views echo U.S. concerns about increasing Chinese influence through the BRI. A few academics have advocated a pro-BRI stance. They argue the BRI is just another expression of the structural shift in the region brought on by the rise of China and will go ahead with or without Australia. They suggest that Australia could define the way it engages with the BRI and, by gaining a seat on the negotiation table in the early days,

Many Western

observers are

concerned about increasing Chinese influence through the BRI. push for "the principles of transparency, private sector engagement and ensuring that infrastructure investment leads to strong development outcomes." 45

To date, Australia has not openly endorsed the BRI. Various reasons have floated from concerns that it may damage its relations with the United States or compromise Australia's technology security to the argument

43 “Japan and 'One Belt, One Road,"' Japan Times, June 24, 2017, http://www.japantimes. co.jp/opinion/2017/06/24/editorials/japan-one-belt-one-road/\#.WYJ2DBWGOpo.

${ }^{44}$ Rory Medcalf, “Mapping Our Indo-Pacific Future: Rory Medcalf's Public Lecture," Asia and the Pacific Policy Studies, June 5, 2018, https://asiaandthepacificpolicystudies. crawford.anu.edu.au/news-events/news/12677/mapping-our-indo-pacific-future-rory-medcalfs-public-lecture. See also "Goodbye Asia-Pacific. But Why the Sudden Buzz Over IndoPacific?" South China Morning Post, December 31, 2017, https://www.scmp.com/week-asia/ geopolitics/article/2126210/goodbye-asia-pacific-why-sudden-buzz-over-indo-pacific.

${ }^{45}$ James Laurenceson and Elena Collinson, "Belt and Road Will Go Ahead With or Without Australia," Lowy Institute, July 13, 2018, https://www.lowyinstitute.org/the-interpreter/belt-and-road-will-go-ahead-or-without-australia. 
that as a developed economy, Australia is less interested in infrastructure cooperation with China and has concerns about development standards associated with BRI projects. ${ }^{46}$ Such concerns reflect unease in Canberra not only with China's growing material power, but also of being in a region where one of the largest and most powerful actors does not share the same liberal tradition. Even so, in September 2017, Trade Minister Steven Ciobo reportedly signed a memorandum of understanding $(\mathrm{MoU})$ with China on infrastructure cooperation that covers the BRI. ${ }^{47}$ Details of this agreement remain unclear, as does Australia's official position on the BRI.

\section{New Zealand}

New Zealand signed a memorandum of arrangement (MoA) with China on the BRI during Premier Li Keqiang's visit in March 2017. It reads differently to previous MoAs that have a strong focus on development and infrastructure cooperation as would be expected from developing economies entering BRI arrangements. For New Zealand, like Australia, connecting New Zealand's 30-year infrastructure project to the BRI was floated as an idea, ${ }^{48}$ but ultimately the agreement was re-written to focus more on exploring areas of cooperation relevant to the bilateral relationship and more suited to New Zealand's economic situation as an advanced economy. The areas of focus include policy coordination, bilateral cooperation, cultural exchange and multilateral cooperation. ${ }^{49}$

${ }^{46}$ Andrew Greene, "Foreign Minister Julie Bishop Delivers Warning to China on Need to Embrace Democracy," Australian Broadcasting Corporation, March 14, 2017, http://www.abc. net.au/news/2017-03-14/julie-bishop-warns-china-on-need-to-embrace-democracy/8350968.

${ }^{47}$ David Wroe, "Foreign Affairs Ministry Opts for Secrecy Over China Infrastructure Agreement," Sydney Morning Herald, July 30, 2018, https://www.smh.com.au/politics/federal/foreign-affairs-ministry-opts-for-secrecy-over-china-infrastructure-agreement20180730-p4zufm.html.

48 “Prime Minister Bill English Meets With Wang Yi,” Xinhua News, February 9, 2017, http://www.xinhuanet.com/english/2017-02/09/c_136043799.htm; and "New Zealand PM Meets Visiting Chinese FM Wang Yi," Chinese Foreign Ministry, February 9, 2017, http:// www.fmprc.gov.cn/ce/cegh/eng/zgyw/t1437844.htm.

49"Memorandum of Arrangement On Strengthening Cooperation on the Belt and Road Initiative Between The Government of the People's Republic of China And The Government of New Zealand," Belt and Road Portal, March 31, 2017, https://eng.yidaiyilu.gov.cn/zchj/ sbwj/10479.htm. 
Responses to the agreement have varied. Many have argued New Zealand's best interests lie in "participating in international initiatives that have the potential to benefit our economy and society" such as the BRI. ${ }^{50}$ Others have echoed U.S. and Australian concerns over "a new economic and strategic bloc." ${ }^{51}$ In the business community, the BRI has received little attention; but when it does, the general discussion is positive but lacking in clear substance, arguably due to the lack of clear projects to date. One business group has produced an extensive review and report on potential opportunities for New Zealand involvement complete with policy recommendations for the government. ${ }^{52}$

\section{Among the developed}

economies, New

Zealand and Japan

have responded

more positively to the BRI.

In May 2018, Prime Minister Jacinda Ardern presented a nuanced view of New Zealand's engagement with the BRI, stating that "The Belt and Road Initiative is a priority for China. New Zealand is considering areas we want to engage in the initiative, and other areas where we will be interested observers." ${ }^{53}$ Like other advanced economies, New Zealand is keenly aware that its external environment has become more challenging as "[g]reat power rivalries have intensified," 54 and that China has become

50 “New Zealand's Senior Official to Attend Belt and Road Forum in Beijing," Xinhua News, May 13, 2017, http://www.xinhuanet.com/english/2017-05/13/c_136279583.htm.

${ }^{51}$ Anne-Marie Brady, "Looking for Points in Common While Facing Up to Differences: A New Model for New Zealand-China Relations," University of Canterbury, November 14, 2017, http://www.canterbury.ac.nz/media/documents/research/Looking-for-points-in-common-while-facing-up-to-differences.pdf.

52 “Belt and Road Initiative: A Strategic Pathway," New Zealand China Council, March 1, 2018, https://nzchinacouncil.org.nz/wp-content/uploads/2018/04/NZCC-BRI-report-19Mar-18.pdf.

53"Speech by Rt Hon Jacinda Ardern to the China Business Summit in Auckland," Beehive.govt.nz., May 14, 2018, https://www.beehive.govt.nz/speech/china-business-summit.

${ }^{54}$ Rt Hon Winston Peters, “Next Steps,” Beehive.govt.nz., June 29, 2018, https://www. beehive.govt.nz/speech/next-steps; and Sam Sachdeva, "Peters Plans 'Pacific Reset,"' Newsroom, March 2, 2018, https://www.newsroom.co.nz/2018/03/01/93439/peters-planspacific-reset\#. 
"more confident in pursuing its aims, which include striving for greater connection through a range of new proposals, such as the Belt and Road Initiative." $^{\prime 55}$

New Zealand has welcomed China's emergence as a key part of global trade and the international trading system and responded in good faith to the BRI. But at the same time, there remains a keen observance of how the BRI adheres to international standards as well as a careful eye on the growing strategic rivalry between the United States and China.

\section{The Ideational Basis of Response}

From the above review, variations in responses to the BRI are observable within and across advanced economies. Some advanced economies, such as Japan and New Zealand, have responded more positively toward the initiative than others, such as the United States and Australia. There is considerable debate across security and economic sectors and within different parts of the business communities. From an ideational viewpoint, however, there is clear consistency in the intellectual frames employed to interrogate and respond to the BRI. In general, there are four types of responses in the advanced economies that reflect the dominance of liberal and realist paradigms: liberalism with a focus on the economy; liberalism with a focus on the economy and politics; realist and mercantilist zero-sum considerations; and confusion followed by a default to one of the previous positions.

The first response is to view the BRI through the framework of economic liberalism and to argue that the initiative can promote economic integration and economic globalization. Businesses, business associations and some parts of government in the advanced economies have interpreted the BRI in this way and are more positively predisposed to the initiative. This follows a general positivity expressed by business interests in the advanced economies toward China's reform and opening, as well as the creation of space within China for private economic interests,

55“New Zealand Strategic Defence Policy Statement 2018," New Zealand Ministry of Defence, July 6, 2018, https://www.defence.govt.nz/publications/publication/strategicdefence-policy-statement-2018. 
including foreign investment and sales to the increasingly affluent Chinese population.

All of the advanced economies have an element of this view of the BRI. Economists have sought to write their economies into the BRI as a way of increasing economic opportunities with China through increased engagement, including in third markets. This response is, however, complicated by the liberal economic tradition and commitment to multilateralism, as well as WTO conceptions of free trade and international standards on investment, procurement, labor contracting, environmentalism, and so on. This is particularly strong in the EU response, but also in Japan, Australia, and New Zealand. This has been less of a focus in the United States where zero-sum considerations have come further to the fore in recent years.

The second response is as above but complicated by the Western commitment to the promotion of political liberalism in the region. Governments and scholars in advanced economies have questioned the impact of the BRI, as an initiative that does not link development with liberal multi-party democracy and good governance in the region. They worry that the promotion of political liberalism could be undermined by states becoming more reliant on Chinese economic engagement and relatively less so on international organizations and the advanced economies, thus undermining their ability to promote a world of liberal democracies.

China needs to

promote the

transparency and

positive-sum impact

of the BRI.

The third response is to view the BRI through the realist and mercantilist paradigm and to worry about zero-sum game and power shifts and to see increased Chinese engagement in the region as a threat to the power and influence of the existing advanced economies. This is currently a dominant theme in U.S. policy-making and strategic studies, but also highly relevant in the assessment of all countries including the advanced economies of the EU, Japan, Australia, and New Zealand. Shifting this assessment will require evidence to demonstrate a positive-sum impact of the BRI.

All the examples above show the debate swinging between zero-sum and positive-sum thinking. In some of the advanced economies, economic nationalism and security interests have taken precedence over more 
engagement-focused analysis of the BRI. Responses in New Zealand and Japan are openly more focused on engagement. Australia and the United States are more concerned with protection of their national security and economic interests in a mercantilist sense. The EU is an interesting case, remaining squarely in the liberal engagement camp but struggling to find a way to engage with the BRI on liberal terms.

The fourth and arguably most common response is to not understand what is being proposed through the BRI. This occurs due to use of unfamiliar concepts. Such concepts include a "community of shared future for mankind," "globalization 4.0," "new regional order and structure," "southsouth cooperation," and a "new model of strategic cooperation." BRI texts refer to "shared winnings/win-win," "common development," and "mutual benefits and interests." They point to a "China dream" for the world and advocate a more "inclusive economic system" and a "new order." Such terms remain unfamiliar in the advanced economies. They represent an effort by Chinese scholars and policymakers to increase China's "international discursive power" and to frame contemporary international affairs. Such terms and concepts have limited impact in advanced economies dominated by liberal thinking and are treated with skepticism by realist scholars.

A perceived absence of a commercial rationale for some BRI projects leads realists to interpret projects on the basis of realist assumptions about state behavior. These assumptions are based on historical lessons that states will always seek to increase their power and advance their own interests. There is no place for altruism in realism. So, in the absence of a clearly recognized motivation for BRI projects, realists will assume China is seeking to improve its national power and influence in a bid for regional hegemony. Realists predict that China will behave like other great powers and therefore reject the BRI concepts mentioned above.

Similarly, the new ideas and concepts in the BRI, as well as a lack of transparency around conditions in the projects, have raised concern of the extent to which the BRI adheres to the principles and norms that underpin the global trading system. Clear statements and demonstrations that BRI projects supplement and align with these norms would go some way to alleviating liberal economic concerns in advanced economies - that the BRI is not seeking to work around or undercut the norms and standards of the global economy. 


\section{Conclusion}

This paper shows that liberalism and realism remain the dominant frames for the reception and response to the BRI in the advanced economies. This, accompanied by the prevalence of Anglo-American concerns, makes reception of the BRI in the advanced economies more challenging than in developing economies. Moreover, with little articulation of how advanced economies will contribute to and participate in the initiative, combined with limited articulation of how the BRI adheres to existing norms and standards, commentators in advanced economies have struggled to write themselves into the initiative, leading to critical and slow responses and thus a lack of buy-in from the advanced economies.

Because liberals have struggled to articulate the BRI in terms familiar and digestible to a local audience, the gap has been filled by realist analysis. This is made possible by what appears to be unclear commercial rationales for some BRI projects and unwillingness in the advanced economies to engage the BRI on the terms presented. Realist analysis has therefore framed the BRI as a China-centered initiative to increase Chinese influence within the region at the expense of existing advanced economies. Liberal analysis has questioned the adherence of the initiative to existing norms and standards of the liberal economic order. The dominance of liberal and realist thought, therefore, goes some way to understanding and interpreting the critical or slow response to the initiative in the advanced economies.

Chinese policymakers and scholars will likely struggle to promote Chinese initiatives like the BRI in the advanced economies without first taking care to understand how they fit within the logic and values of the dominant IR frameworks. Liberals in the advanced economies have experienced something similar in their promotion of liberalism with China. Put another way, the BRI could provide the stimulus for recognizing the need for renewed efforts to co-create new thinking on regional development through intellectual engagement. This will require far greater intellectual debate than is currently occurring. Such discussion is a prerequisite for the avoidance of overlapping but rival regional blocs with competing norms and standards emerging. 